\title{
DEVELOPING SKILLS IN SECURING SAFETY WHEN TRAVELLING AS AN ADDITIONAL EDUCATIONAL NEED OF SCHOOL CHILDREN AND YOUNG PEOPLE
}

\author{
Marcin PASEK, PhD \\ e-mail: marcin.pasek@awfis.gda.pl \\ Remigiusz DRÓżDż, PhD \\ Tomasz KOCHAŃCZYK, PhD \\ Faculty of Tourism and Recreation \\ Gdansk University of Physical Education and Sport
}

\begin{abstract}
Safeguarding the functioning of local and international tourism is one of the most important social challenges. Mastering its principles is a prerequisite for success in the fulfilment of such human needs as relaxation, wellbeing and exploration of the world. The effectiveness of any steps to limit the risk and its consequences in tourism stems from multiannual observation of social phenomena, but it is also dependent on the level of theoretical preparation to take practical action for increased security at every stage of the journey. The aim of this article is to explore the idea of developing skills in securing safety in travel as an additional educational need of school children and young people. The article recommends supplementing the school curriculum at the primary and secondary school level in order to help create a profile of a student able to secure broadly understood safety for himself and for others.
\end{abstract}

Keywords: safety, risk, tourism

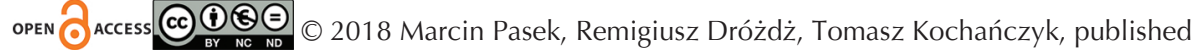
by War Studies University, Poland

This work is licensed under the Creative Commons Attribution-NonCommercial-NoDerivatives 4.0 License. 


\section{Introduction}

Travelling around the world since its beginnings in antiquity has always involved many hazards. With time, the range of these hazards has been slowly diminishing. The prospect of health or loss of life on the path of warfare, trading route or in pilgrimage made each generation do something practical to ensure a safe trip. In time, such actions covered not only transport from place to place, but also preparations for the journey and the stay at the destination point. Nowadays, people often don't organise tourist trips by themselves but share the responsibility for their own safety with tourist offices, hotel industry personnel and others responsible for organisation of tourism, such as local administration employees, local catering establishments, public service workers or staff of recreation facilities. Due to the school safety curriculum, students of primary and secondary schools should be able to organise safe time after school and later in life, time free from public responsibilities. The range of these skills is dependent, on the one hand, on personal involvement in the education process and, on the other, on the education curriculum. The broad spectrum of issues included in this programme should become an indicator of both quality of education and comprehensive preparation of a graduate for securing safety in recreation under all circumstances.

The planned termination of junior secondary schools now functioning under temporary regulations and the return to the system of 8 class primary schools and vocational schools of 1st degree, technical schools and grammar schools, will enforce reconstruction of current curriculums. The provision of the Minister of National Education of 14th June (Dziennik Ustaw 2017, poz. 1239, tom 1) changing the previous provision of 2009 (Dziennik Ustaw 2009, poz. 1131) regarding the method of carrying out security education, recommends organising specialist training-recreation camps in security education based on principles defined in the statute of 7th September 1991 about recreation for children and young people (Dziennik Ustaw 2017, poz. 2198). The plan emphasises the role of safe behaviour in free time in unusual social and natural conditions.

The purpose of the article is to present the idea of development of skills in travel safety as an extra educational need of young pupils. In other words, the article examines the proposal regarding supplementing the educational curriculum for students with safety in tourism and recreation to such an extent that it may become 
a guarantee of their feeling safe during tourist trips. The suggested content of the school curriculum should become part of the subject called security education. With regard to that objective, we should ask ourselves a question about the significance of safety during school tourist trips in the system of education. We may think that such issues are marginal at that stage of education, but their traces appear in analyses of issues concerning hazardous situations, the rules of first aid and behaviour promoting health.

\section{General guidelines for Security Education curriculum in primary schools}

The starting point for the safety curriculum in primary school is the Provision of the Minister of National Education of 14th February 2017 which draws up guidelines for preschool education and general education in primary schools (Dziennik Ustaw 2017, poz. 1239). The general objectives introduce the idea of national security, preparing students for acting in situations of high risk and developing their knowledge about first aid as well as shaping individual and social behaviour promoting health. The above objectives are accompanied by the suggestion of a sensible reduction of theoretical content and an emphasis on the practical character of proposals for students.

The teachers have at their disposal 33 hours of security education lessons in class 8 of primary school. In the suggested curriculum (Słoma 2017), 27 subjects have been planned and presented and the most important of them were consolidated into two hour blocks. There is a suggestion that the remaining hours be devoted to revision of information and checking students' progress as well as supplementing the information and providing additional skills practice. This additional time can be used to learn theoretical issues of safety in tourism and recreation as related to practical activities during training-recreation camps. According to the guidelines of the above mentioned Provision of the Minister of National Education of $14^{\text {th }}$ February 2017, the camps should take place during winter holidays - for students of 8th class of primary school or 1st class of secondary school. By linking theory with practice, the acquired skills and knowledge are to inspire students to further development towards full responsibility in adult life for securing safety in their surroundings. 


\section{General guidelines for Security Education curriculum in secondary schools}

According to the statute, compulsory security education on this level includes secondary vocational schools, grammar schools, profiled secondary schools and technical schools. The total number of hours at this stage of education amounts to 30 hours of lessons. The programme guidelines for the subject include the following educational objectives and general requirements connected with them: structure of national defence, preparations for hazardous situations and the principles of first aid. The implementation of security education focuses on revision and slight extension of the content from the earlier stage of education. The revision of first aid skills is a positive phenomenon because The European Council for Resuscitation recommends revision of training every two years (Kłos 2013).

The safety and national defence content and practice are, however, grossly marginalised. This is an alarming phenomenon that requires determined action such as the introduction of changes to the curriculum and an increased number of hours in the educational cycle. This situation may partially be caused by the social conviction that paying taxes and the existence of a professional army excuses an ordinary citizen from an obligation to learn defensive skills (Kłos 2013). In this case, similarly to the stage of primary school learning, the development of habits to increase individual and social safety may take place during tourist-recreational special camps devoted to the theme of security education during winter and summer holidays. The knowledge and skills learned there may be supplemented with 180 minutes provided in the curriculum of Security Education at the teacher's individual disposal (Kłos 2013).

\section{Elements of Security Education in tourism and recreation}

Infrastructure conditions of safety in tourism include safe organisation of touristrecreational centres at lakes, at the seaside and in mountain regions including adaptation of tourist and recreation facilities to the needs of tourists, especially those who are disabled (Dróżdż 2015), and also for the safety of tourists on tourist 
trails. Learning the principles of safety in tourism and the hotel industry, including safety and hygiene at work and ergonomics, the graduate can assess the level of service provided by tourist-recreational infrastructure and avoid dangerous behaviour with respect to such situations as the unknown depth of recreational basins, the absence of chains securing a mountain ridge, construction defects of open air fitness facilities and many others.

\section{Security in the event of terrorist attack}

Considering the increase in terrorism in recent decades, which also affects the tourist-recreational industry, the issue of reaction to threats should be learned at all stages of education. Good solutions in this respect come from the US where they were a response to terrorist attacks in Washington and New York in 2001. The antiterrorist education programmes are meant to draw attention to all threats such as suspicious vehicles and people or untypical, abandoned objects. They are concerned especially with mass participation events and public places such as supermarkets and means of public transport. A tourist who finds himself at the centre of threat should immediately inform respective services (police, city guards, building administration) and if there is an evacuation or rescue operation, he should take orders from the people in charge. In the event of capture by terrorists, it is a valuable skill to turn the assailants' attention to the fact that they are dealing with human beings as well as remaining calm and assuming a balanced attitude between aggressiveness and passivity and submissiveness. It is also very important to remove all signs of having an important position among the group of tourists who have been captured (https://mswia.gov.pl).

\section{Safety of objects of cultural heritage}

Education for the protection of cultural heritage is the result of the progressive lack of safety inside and in the vicinity of cultural objects. Numerous examples of threat to cultural heritage such as excessive numbers of tourists, robbery, adverse climate conditions, terror, war, fire, natural disaster, acid rain and other examples 
of environment pollution, excessive salinity or microbiological threats make it necessary for organisers of tourist traffic to take preventive steps, with state administration taking a leading role. Understanding the need to act professionally and know basic problems related to evacuation of people from sacred and civil historical buildings may result in effective cooperation with the police or fire services (Jakubowski 2015).

\section{Epidemiological basis of safety}

Relations between tourism and epidemiology embrace many issues whose importance increases in situations when it is necessary to act correctly in the face of natural disasters and warfare, which are the most serious sources of epidemiological threats. Potential biological weapons used in bioterrorist operations may be viruses containing anthrax, pox or botulin and toxins produced by algae and cyanide bacteria. The information about threats resulting from contamination of food and water and the effects of ionizing radiation on the human body may become important from the point of view of developing tourist traffic to the Prypeć and Czernobyl areas affected by the nuclear reactor failure in 1986 (Marek 2011).

A separate chapter in this range of problems is devoted to the epidemiology of selected infectious diseases posing a threat to tourists: amoebiasis, diarrhea caused by rotavirus, boreliosis, cholera, dysentery, denga fever, bubonic plague, ebola, tick related encephalitis, legionellosis, rabies, malaria and the HIV virus (https://gis.gov.pl/zdrowie/choroby-zakazne?start=50).

An important skill acquired in the course of education is correct identification of chosen biotic and abiotic threats to human health. As a result, a tourist can demonstrate a satisfactory social awareness of responsibility for his and others safety. 


\section{Safety of food and nutrition in tourism and hotel industry}

An important role in the education system should be played by education for safety in nutrition in tourism. Knowledge of this includes the basis of rational nutrition, food toxicology, ways to safely store and prepare food products and the principles of the ergonomics of work stations in the kitchen area and in the back of multifunctional rooms in hotels (Sitarz and Janczar-Smuga 2012). Apart from other important aspects of nutrition in tourism, this knowledge creates favourable conditions for development of skills to implement various dietary recommendations for specific groups of people. The most important social skill is the inner need to be responsible for obeying rational nutrition principles and understanding the consequences of failure to obey them.

\section{Biological and social aspects of active tourism and safe recreation}

Biological and social aspects of active tourism and safe recreation should be taught in relation to their importance in situations of threat. Knowledge of these aspects may be particularly useful for tourist guides, expedition organisers and paramedics. These issues include rules of safety in selected types of mountain qualified tourism, skiing, cycling and canoeing, selection of clothing and shoes with respect to hygiene, safety and ergonomics as well as the choice of place and gear for a bivouac. Knowledge of the principles of behaviour when there is a threat to the life and health of tourists (such as accidents with injury and sudden sickness) includes correct interpersonal communication and cooperation in a group. A lot of space should be devoted to the significance of fitness preparation and health condition in maintaining a safe level of effort (Drogosz 2009, p. 43).

\section{Environmental health risks}

Environmental health risks in the ecological sense may come from abiotic or biotic sources and often put tourists' health or life directly at risk. The first group among the physical factors and reaction to them includes the negative health 
effects of radiation, the defensive reaction of organisms in contact with hot and cold surroundings, dehydration of the body and its disturbed functioning at high altitudes (altitude sickness) as well as the influence of high hydrostatic pressure during tourist diving. In relation to bathing in water, a health risk appears in relation to pollution of waters by carbolic acid or tensid chemicals, and in the case of air - pollution with heavy metals coming from such sources as industry and transport. They constitute examples of abiotic chemical influence on the health of people involved in active tourism. Many health restrictions are also present in forest ecosystems and the most important of them are fire hazards, blowdown areas, plant allergenic pollen, rabies, venomous animals, sicknesses carried by ticks and allergenic reaction to mosquito or Acuelata bites (sting insects) (Riedl and Pasek 2014). The result of education in this area should be to improve the correct selection of sources related to safety in the tourist-ecological environment and their use in the tourist industry. Young people on bivouacs and those going in for active tourism may benefit from these skills in safety risk situations.

\section{Safe participation in mass tourist events}

Safe participation in mass tourist events requires knowledge of the legal basis of safety at tourist events, respecting European standards in the prevention of criminal acts during such events and recognising the role of the media in shaping the behaviour of participants at tourist events (Strugarek 2011, p. 5).

A student who has knowledge in this field can identify the source of conflicts appearing before, during and after organised tourist events and can carry out a planned tourist event by himself with a realistic assessment of the degree of safety. He can also effectively communicate with the authorities directly responsible for issuing permission for tourist events. 


\section{Safety in transport}

Since tourism and transport are rapidly developing areas in globalised reality, they require particular reference to safety issues. One of the first important acts related to passenger rights was the White Book (published in 1992) which led to a higher quality of services and ensured basic rights for tourists using all kinds of transport especially with regard to passengers with limited abilities to move (Adamowicz and Paśko 2014). The field of broadly understood tourism and transport, apart from offering many opportunities and possibilities, is also open to many risks.

Undertaking the subject of safety in tourism and transport is an answer to the growing interest in this type of activity and the need to increase its safety. The issues of safety during transport of tourists at a passenger terminal, during a journey by plane, coach, car, rail or ship should be analysed in detail. They refer to the possibility of terrorist attacks, transport accidents, meteorological disturbance, unplanned breaks or delays, failure of means of transport, control of sobriety of service staff, checking the presence and health of tourists during a journey. The knowledge of principles of conduct in the mentioned cases is to guarantee safe use of means of transport.

\section{Principles of safety and hygiene at work and ergonomics as part of tourist activity}

Principles of safety and hygiene at work and ergonomics as part of tourist activity are mostly the concern of tourist offices, but we should not forget about some of their aspects during a tourist trip such as safe conditions for the driver of a coach, the ergonomics of his work station and seats for passengers and having a first aid kit and fire extinguisher which must not only be mandatory technical equipment during such transport but must also be available at a hotel or another place which is a sleeping base for tourists. A customer of a tourist centre has the right to safe hygiene and sanitary conditions including thermal comfort, acoustic, lighting or sanitary comfort (Dróżdż and Marzec 2015, p. 111). A student who has learned about such regulations can effectively assess the risk at the place of recreation and develop responsibility for his personal and other people's safety. 


\section{Conclusions}

The purpose of the article is to present the idea of developing skills for keeping safe during a journey as an additional educational need of school youth. The adopted objective resulted in presenting suggestions of supplementing school curriculums with safety in tourism and recreation lessons in such a broad scope that it may become one of the guarantees of feeling safe on tourist trips. The authors believe that the suggested educational content should be part of the curriculum of a school subject called education for safety.

The variety of issues presented for the most complete discussion of the subject of safety in tourism and recreation may become an encouragement to include them in school curriculums in primary and secondary schools. The greatest chances for creating social awareness of safety in tourism are connected with multifaceted knowledge acquired on the mentioned stages of education when great chances exist to shape positive behaviour in this field. This promising perspective must, however, ensure that the existing issues of security education in the school curriculum must remain intact. However, the social needs of safe travelling around the country and the world are growing and are still not reflected in the system for educating students whose requirements should be more and more focused on the effective introduction of the young generation into undertaking social roles connected with ensuring safety.

\section{References}

Adamowicz, M. and Paśko, M., 2014. Ochrona praw pasażerów - europejska wizja. Turystyka. Nowe trendy. Zeszyty Naukowe Europejskiej Szkoty Wyższej w Sopocie 3. Drogosz, M., 2009. Krajoznawstwo i turystyka w szkołach i placówkach oświatowych. Poradnik dla dyrektorów i kadry pedagogicznej. Wolters Kluwer Polska, Warsaw.

Dróżdż, R. and Marzec, R., 2015. Bezpieczeństwo w turystyce i hotelarstwie - wybrane aspekty. Europejska Szkoła Wyższa, Sopot.

Dróżdż R., 2015. Przystosowanie obiektów hotelarskich w Trójmieście dla potrzeb osób niepełnosprawnych. Turystyka. Nowe trendy. Zeszyty Naukowe Europejskiej Szkoty Wyższej w Sopocie, 4. 
Dziennik Ustaw 2009, poz. 1131, rozporządzeniu Ministra Edukacji Narodowej z dnia 28 sierpnia 2009 r. w sprawie sposobu realizacji edukacji dla bezpieczeństwa.

Dziennik Ustaw 2017, poz. 1239, Rozporządzenie Ministra Edukacji Narodowej z dnia 14 czerwca 2017 r. zmieniające rozporządzenie w sprawie sposobu realizacji edukacji dla bezpieczeństwa.

Dziennik Ustaw 2017, poz. 2198, fragment Ustawy z dnia 7 września 1991 r. o systemie oświaty. [online].Availablefrom:https://gis.gov.pl/zdrowie/choroby-zakazne?start=50 [Accessed 6 Jan 2018].

https://mswia.gov.pl [Accessed 6 Jan 2018].

Jakubowski, O., 2015. Zagrożenia dziedzictwa kulturowego na świecie. Santander Art and Culture Law Review, 1.

Kłos, P., 2013. Edukacja dla bezpieczeństwa jako element przygotowania obronnego młodzieży. In J. Walczak and C. Sochala (eds), Wspótczesne wyzwania obronności. Stowarzyszenie Ruch Wspólnot Obronnych: Mcopy Paweł Żerański, Wyszków.

Marek, A., 2011. Zamknięta strefa rejonu Czarnobyla jako miejsce destynacji turystów. Stupskie Prace Geograficzne, 8.

Pasek, M. and Ziółkowski, A., 2014. Ekologiczny wymiar kultury fizycznej. Wydaw. Uczelniane AWFiS, Gdańsk.

Riedl, T. and Pasek, M., 1999. Żądłówki (Acuelata) i kleszcze (Ixodida) jako zagrożenie dla kuracjuszy i rekreantów. Materiały z międzynarodowej konferencji naukowej nt. Turystyka uzdrowiskowa. Stan i perspektywy, Jastrzębia Góra.

Sitarz, S. and Janczar-Smuga, M., 2012. Współczesne zagrożenia bezpieczeństwa żywności, możliwości ich kontroli oraz eliminacji. Nauki Inżynierskie i Technologie, 2 (5).

Słoma, J., 2017. Program nauczania edukacji dla bezpieczeństwa w szkole podstawowej. [online]. Available from: https://dlanauczyciela.pl/27338,program-nauczaniaedukacji-dla-bezpieczenstwa-w-szkole-podstawowej-pdf [Accessed 6 Jan 2018].

Strugarek, J., 2011. Organizacja $i$ prowadzenie imprez sportowych, rekreacyjnych i turystycznych. Wydaw. Uniwersytetu im. Adama Mickiewicza, Poznań. 